\title{
A Commercial Feasibility Study on Recycled Concrete Aggregate (RCA) in Bangkok Dealing with Random Parameters
}

\author{
Tanakan Chua ${ }^{1, a}$, Punnamee Sachakamol ${ }^{2, b, *}$, and Kongkiti Phusavat ${ }^{2, \mathrm{c}}$ \\ 1 Engineering Management, Graduate School, Kasetsart University, Bangkok 10900, Thailand \\ 2 Department of Industrial Engineering, Faculty of Engineering, Kasetsart University, 50 Paholyothin Road, \\ Chatuchak, Bangkok 10900, Thailand \\ E-mail: athechua1@gmail.com, bfengpmsa@ku.ac.th (Corresponding author), cfengkkp@ku.ac.th
}

\begin{abstract}
Demolished concrete is found a lot.In developed countries, there is a clever method to dispose such demolished concrete by recycling to get a near quality as natural aggregate in order to reduce natural resources and help concrete waste disposal which is called recycled concrete aggregate (RCA). However, in Bangkok, it is now no strict regulation to dispose demolished concrete. This research studied a feasibility of RCA in Bangkok by simulation which many criteria in the model were assumed to be random parameters; therefore, this research created a model by Monte Carlo Simulation which is differed from other RCA business model simulations that normally use constant parameters. In additions, four conditions were set, first: 100-ton-per-hour constant supplied plant, second: 50-ton-per-hour constant supplied plant, third: 100-ton-per-hour uncertain supplied plant, and fourth: 50-ton-per-hour uncertain supplied plant. The result showed the trend of output rather than 1 simple output thanks to the random inputs. In details, the both constant supplied plant can make a profit, additionally; 100-ton-per-hour plant was more worthwhile than 50-ton-per-hour plant thanks to the economics of scale. On the other hand, for the uncertain supply, 100-ton-per-hour plant was loss, but 50-tonper-hour plant still made a profit.
\end{abstract}

Keywords: RCA, demolished concrete, recycled concrete aggregate, Monte Carlo simulation, feasibility study.

ENGINEERING JOURNAL Volume 21 Issue 3

Received 7 October 2016

Accepted 14 December 2016

Published 15 June 2017

Online at http://www.engj.org/

DOI:10.4186/ej.2017.21.3.133 


\section{Introduction}

In general of construction life cycle, constructions are built, demolished and revamp or rebuilt again and again in order to respond human's needs. A lot of materials are used for civilization. On the other hand, myriad natural resources especially natural aggregate are depleted by human hand.

The more construction, the more natural aggregate is consumed. Likewise, when demolition is coming, demolished concrete is found a lot.Many countries utilize demolished concrete in many ways depending on a government policy. Normally, the steel is removed for reused, other stone with attaching mortar is used for landfill or turn it into recycled concrete aggregate (RCA). For example, in London Olympic 2012, new buildings or roads are constructed from RCA [1]. In china, Zhengzhou Yifan Machinery Co., Ltd, who supplies Crushing and Screening Equipment, informed that after they turn demolished concrete into RCA, they brought RCA to produce many constructing things. Generally acceptable, using RCA directly helps use less natural resources.

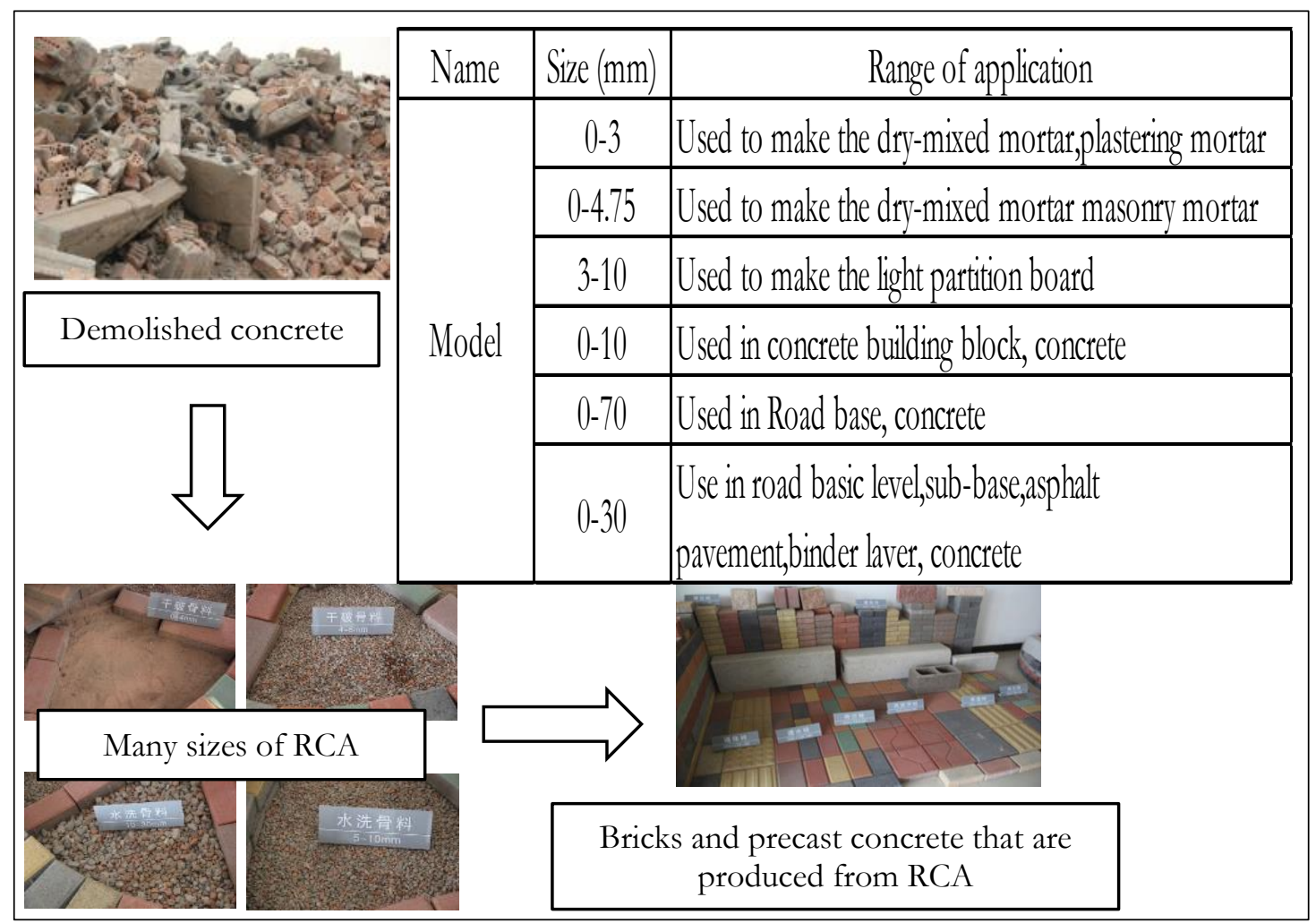

Fig. 1. Normal practice of RCA in China [2].

In Thailand, it is no strict regulation. After steel is removed, big demolished concrete is often put into landfills, a deep soil/sand mines and the worst in the public areas. In the long term, it will destroy natural atmosphere.The demolished concrete was thrown in public area as shown in Fig. 2.
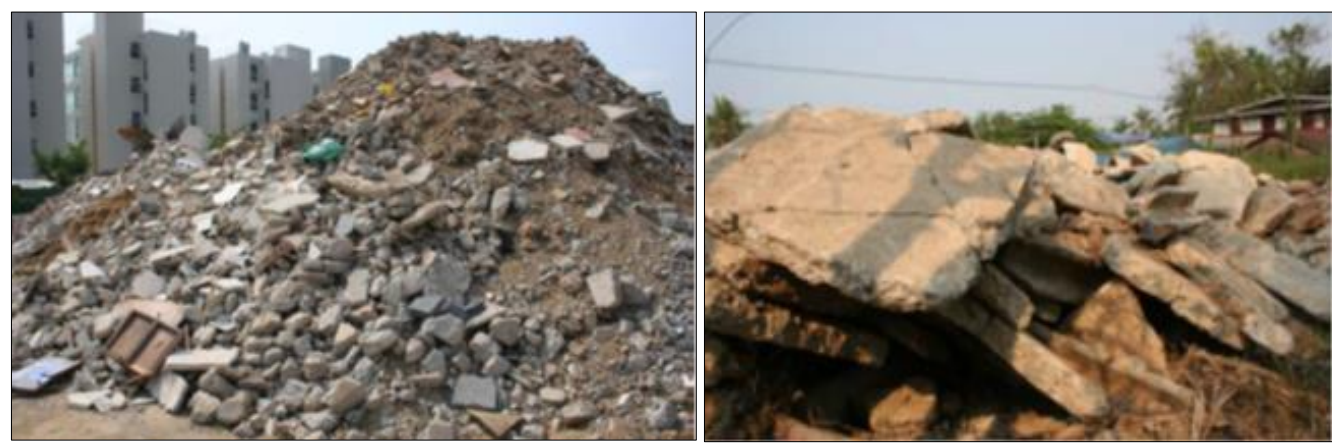

Fig. 2. Demolished concrete in public area of Bangkok [3]. 
Moreover, there is a business that provides free area for a person who wants to throw away demolished concrete and then, selling as it is in low price than natural resources to a person who wants to do landfill.This is also an effortless model, and still causes such environmental problem.To solve this problem, applying RCA technology will help not only environmental problem but also financial benefit to stakeholders.

Nowadays, RCA is studied in 2 ways: First, technical term-How it can be applied in construction as much as possible thanks to the fact that the more recycled, the less consumption of natural aggregate (NA). Many experiments have been tested (gradual mix or add some additives) for the better property and set the standard [4-7]. There are many technologies of concrete recycling processes focusing on RCA's quality. However, the RCA's quality is just one part of concrete' quality. The RCA's proportion mixed in concrete is the other one influence on concrete's quality as well.

The other way, commercial term-How it can be set as a business model to create profit. What are the limitations? In conclusion, almost all models were successful in simulation model, and the bigger plant will generate more profits thanks to the economics of scale [8-11].

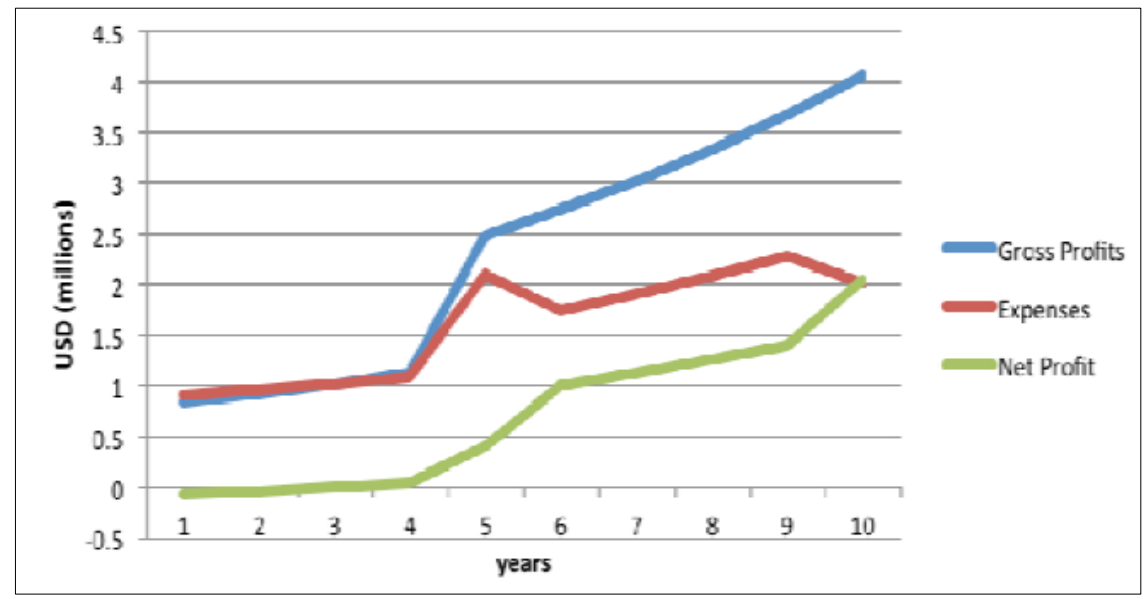

Fig. 3. Example of Profit of RCA Plant in Egypt [11].

However, all models were still not considered about uncertain supply (normally, fix numbers were used for supply equally to machine's capacity.) This research tries to create the model that applies uncertain supplied conditions in order to get much more realistic answers with a probability of the output that can be happened. Therefore, Monte Carlo Simulation which is appropriate for uncertain parameters is applied in this research through Excel which is a famous general program. Besides, after obtaining financial ratio output, the results will be shown, first, a comparison of advantages and disadvantages between a big and a small RCA plants under the constant supply and uncertain supply, second, recommend a proper plant size and third, find out the acceptable buying price.

\section{Materials and Methods}

Before creating each assumption, life cycle assessment of RCA was set in order to see overall background and set the limit of study and was shown in Fig. 4. In details, demolished concrete was assume to be purchased from owner of demolition sites and construction sites or there may be have new job which is collector who collect demolished concrete from each site to sell to RCA plant. After they bring demolished concrete to the plant, RCA was produced, then RCA will be sold to construction material retailers or directly to construction site and some factories which produce product from concreted such as Brick factory. Additionally, the internal process of RCA plant was described in topic 2.1.6 Machine, Capital Cost and maintenance cost. 


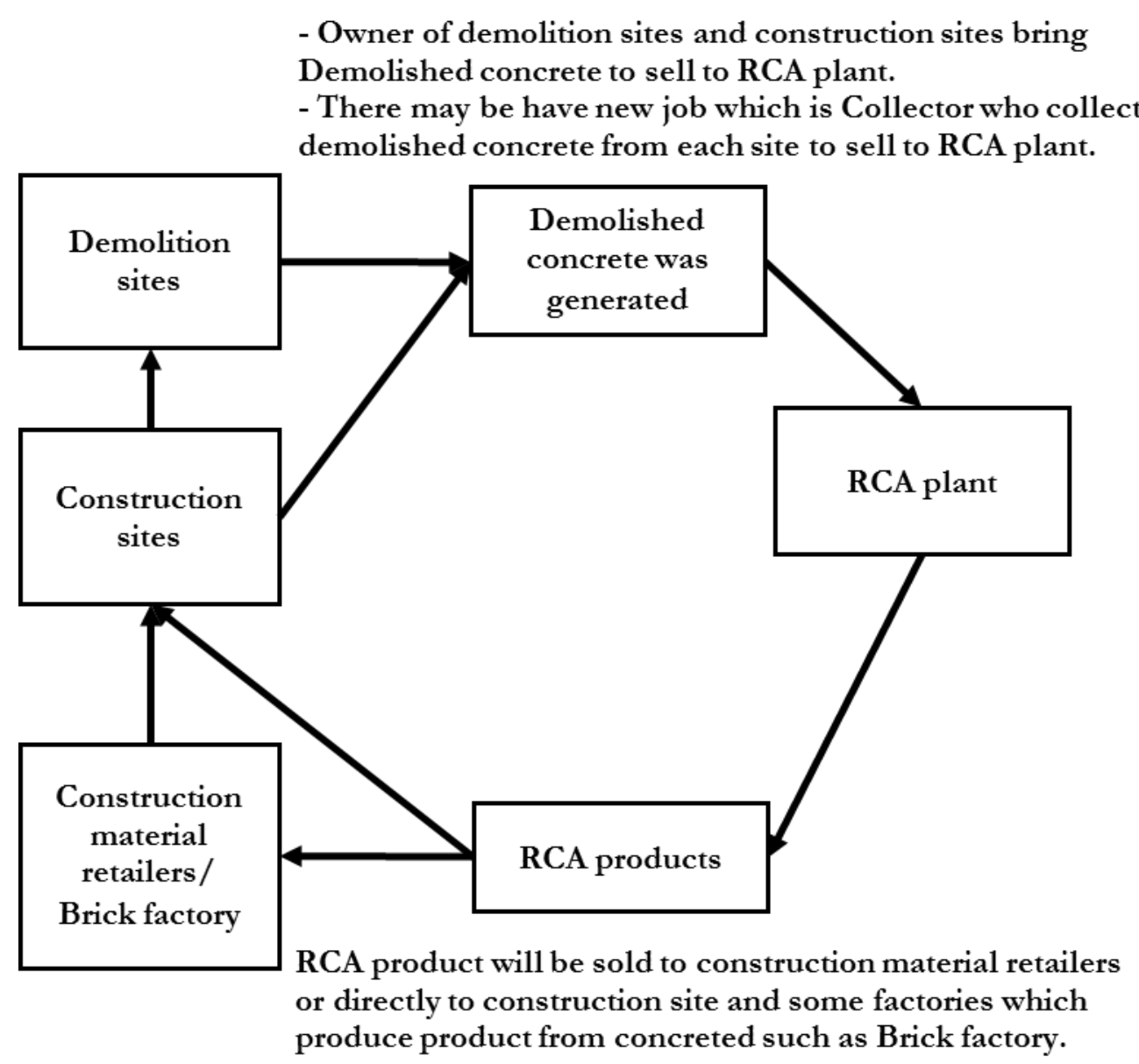

Fig. 4. Life cycle assessment of RCA.

\subsection{Assumption}

\subsubsection{Simulation period}

The model was run for 10 years, because it was a huge investment and can surely see the payback period.

\subsubsection{Demand}

36 million tons of cement was consumed in Thailand in 2009 [3]. There is a lot of demand of coarse RCA even plant 1,000 ton/day still can supply. However, dust (or equivalent to Fine RCA) from the process still does not have research-support that it can be substituted in natural aggregate. Besides, dust is used for land fill and making brick and does not have high consumption. The Coarse RCA was calculated based on substitute natural aggregate about $20 \%$ (This will affect quality less and still can use wildly [5]), besides, it can be sold all how much a RCA plant can produce. Fine RCA demand was assume to be about half of natural dust demand [12].

\subsubsection{Selling price}

Current coarse natural aggregate price was shown in Fig. 5. 


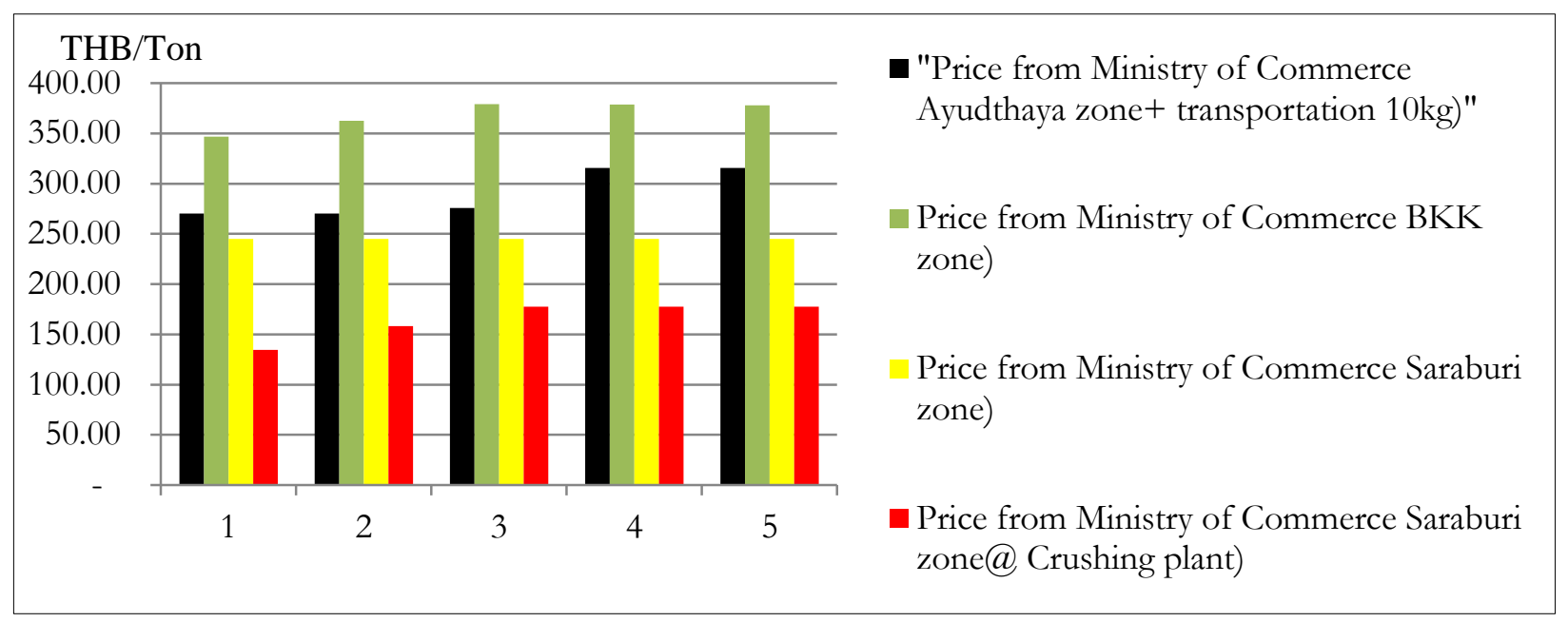

Fig. 5. 5-year trend showed natural aggregate price have increased about $2 \%$ per year [13].

The average RCA selling price in model will be adjusted lower than the natural aggregate price in order to attract in a construction market. The average RCA Selling price was assumed to be constant (to make the model pessimistic). The average scrap steel Selling price was assumed to $5000 \mathrm{Baht}$ per ton.

\subsubsection{Supply}

Bangkok is likely to have enough supply for run the business; however, the problem is that demolished concrete is dispersed and randomly happen (Nevertheless, in the city has a higher chance to happen). A huge transportation cost will be occurred, if we want to collect to meet demand.

In details, The RCA plant can collect demolished concrete basically from 2 sources: Waste in New Construction site and Demolition site. Each had its own character as Table 1.

Table 1. Characteristic of demolished concrete between new construction and demolition.

\begin{tabular}{lcccc}
\hline Characteristic & Occurrence & $\begin{array}{c}\text { Volume } \\
\text { per time }\end{array}$ & Scattering & Frequency \\
\hline New Construction & Random & Small & Wide & Often \\
Demolition & Random & Huge & Normal & Seldom \\
\hline
\end{tabular}

Estimated volume of demolished concrete from new construction

From survey to 11 constructors, it was assumed that from concrete consumption about 613.36 cubic meters per month will create demolished concrete about 6.17 ton/month.

There is concrete consumption in Bangkok zone about 7,020,000 cubic meters per year [14]. And it was assumed that area that the RCA plant support was about 30 percent of Bangkok area.

From all assumptions, using probability to simulate demolished concrete from new construction, it was about 1,059.67 ton per month or 5.09 ton per hour for 30 percent area of Bangkok zone.

\section{Estimated volume of demolished concrete from demolition}

From survey, no any demolisher can estimate generating of demolished concrete. One large demolisher tries to make its company to survive by finding continuously demolition job and this can generate demolished concrete about 20.83 ton per hour.

From Department of business development, there were 17 demolishers registering in Bangkok which shows work capital and revenue. However, from yellow pages website, there were 46 demolishers showing up $[15,16]$. 
It was assumed that area that the RCA plant support was about 30 percent of Bangkok area. From all information, it was assumed that all demolishers will generate demolished concrete as well, and the amount of demolished concrete was calculated from Interpolation. Finally, average demolished concrete from demolition was about 48.08 ton per hour.

Nevertheless, there was the other research about methods of concrete waste disposal from Pollution Control Department of Ministry of Natural Resources and Environment informing that in year 2005, demolished concrete from construction was about 11.10 ton per hour and from demolition was about 36.28 ton per hour [3]. Then made an approximately update to the value by Growth rate of Domestic Production of construction from Bank of Thailand provided [17]. Therefore, it was assumed that currently, demolished concrete from construction was about 12.37 ton per hour and from demolition was about 40.42 ton per hour.

In conclusion, from both assumptions, there were unequal values. Therefore, it was assumed to set those numbers as min and max values; plus losing opportunity of collection about 20 percent. Besides, from the Growth rate of Domestic Production of construction [18], growth rate will be randomly generated at 1.32 percent with standard deviation 5 percent

\subsubsection{Buying price}

There was no data support, what the exact price of demolished concrete was. From the surveys, sometimes, it is free. Sometimes, it has a high value 150 to $200 \mathrm{baht} / \mathrm{Ton}$ (plus transportation cost). And sometimes, we earn money from collecting it. However, from holistic view, in the city (inner area), it is likely to be high value. On the other hand, in the suburb (outer area) it is likely to be less value.

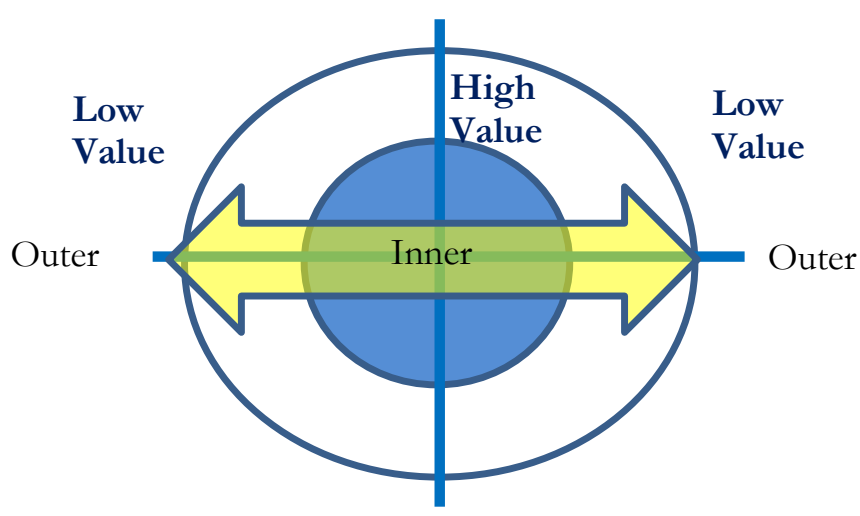

Fig. 6. Value of demolished concrete in Bangkok between inner zone and outer zone.

Therefore, the average buying price will be set as various values starting from 0 baht per ton until it shows unprofitable. (10 baht step-up). (In term of commercial, buying price 0 baht per ton means that RCA plant dispose waste for free. On the other hands, if buying price is higher than 0 baht per ton, RCA plant is paying for dispose waste which is not normal. In fact, customer should pay for the service like other businesses such as car washing. However, in this case, the buying price which was higher than 0 baht per ton was for motivation to collect demolished concrete easier.)

\subsubsection{Machine, capital cost and maintenance cost $[2,19,20]$}

They were used from data collecting. The testing plant' sizes were 50 ton per hour and 100 ton per hour in order to see the different between small and big volumes. The operating time was 8 hour per day and 26 day per months which was a standard practice for running factory.

RCA output sizes were randomly depended on suppliers' information which coarse RCA was about $67 \%$ to $85 \%$. Moreover, there was scrap steel waste which also can be saleable. And it was assumed to be about $0.1 \%$ to $0.2 \%$, because it was normally removed from demolisher.

The basic machines for the plant and the layout of producing RCA were assumed as in Fig. 6 which is standard model. And the processes are as follows: 
1. The major foreign material such as plastic or other wastes that comes with demolished concrete was assumed to be disposed before putting in the demolished Stock by sellers who sell demolished concrete. (In this state to demolished stock yard was equal 100\% input)

2. Pay loader: transport the demolished concrete from demolished stock to Scrap yard, put into feeder and transport the RCA to buyer's truck. (No any loss in this state, still 100\% input)

3. Excavator: miniaturize the demolished concrete and remove seeable steel. (The miner foreign material will be disposed again in Scrap yard by labor in RCA plant; therefore, some of input was turn into output as scrap steel).

4. Feeder: receive demolished concrete to Jaw crusher (No any lose during this state)

5. Jaw crusher: the first crushing step (No any loss during this state)

6. Magnetic separator: remove steel from the process. Therefore, some of input was turn into output as scrap steel including state 3 (about $0.1 \%$ to $0.2 \%$ ) which was fed to scrap steel yard.

7. Vibrating screen: receive RCA from Jaw crusher and Impact Crusher to screen RCA' size. (No any loss during this state)

8. Impact Crusher: receive the over size of RCA from Vibrating screen to the second crushing step. (No any loss during this state)

9. RCA yard: receive RCA from Vibrating screen and there are four piles of RCA depending on size. In this State, the output of RCA size 4 millimeter to 3/4 inch (Coarse RCA) was assumed to be random from $67.0 \%$ to $85.0 \%$, size lower than 4 millimeter (Fine RCA) was assumed to be random from $14.8 \%$ to $32.9 \%$ and the scrap steel from state 3 and 6 was assumed to be random from $0.1 \%$ to $0.2 \%$.

In total, the summation of outputs of Coarse RCA, Fine RCA and scrap steel was equal input of demolished concrete. No any loss of input in the process thanks to the assumption that demolished concrete was assumed to be disposed before putting in the demolished Stock by sellers. However, the randomness still occurred among those outputs

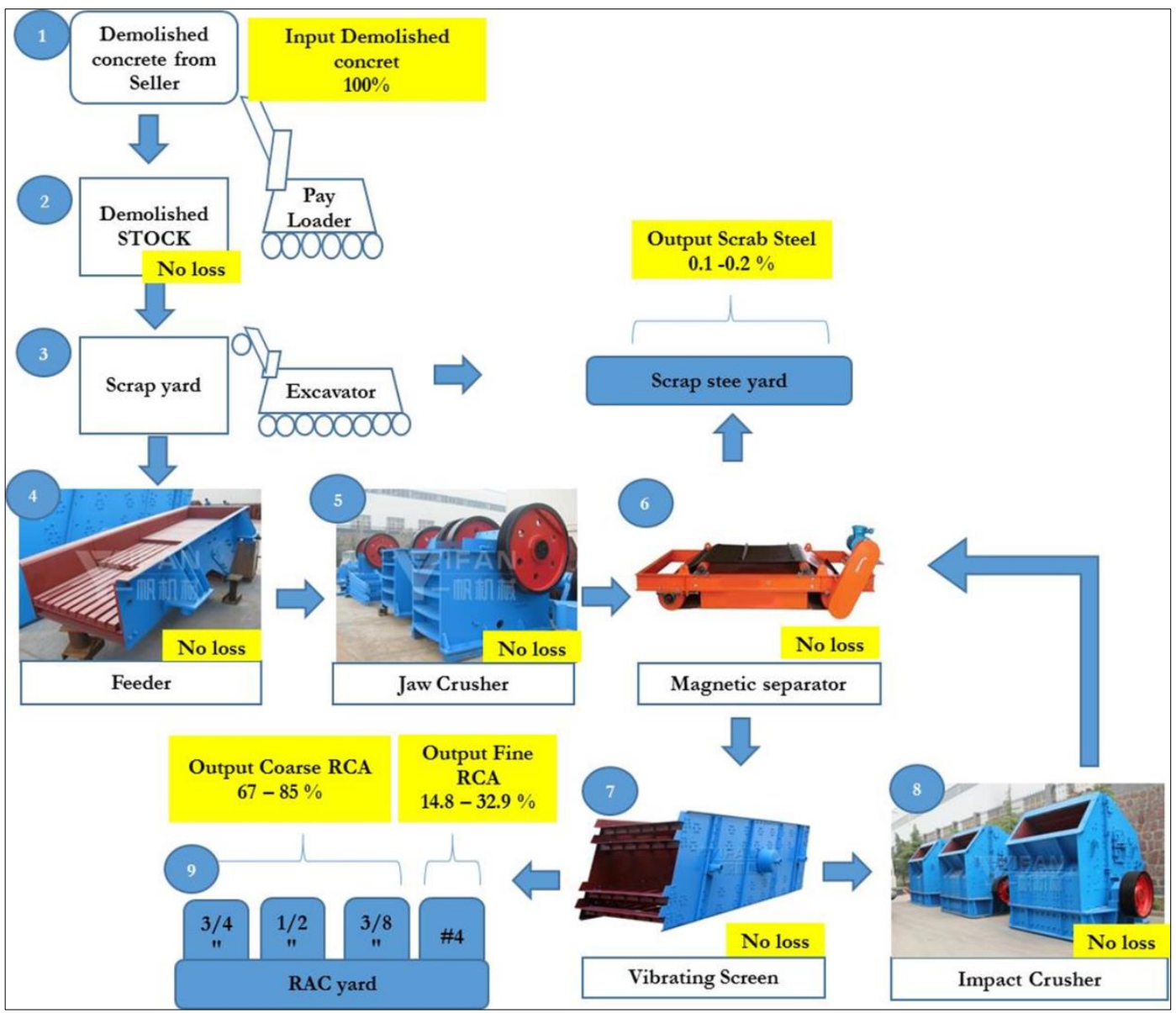

Fig. 7. Machines and processes for the RCA plant. 


\subsubsection{Employment generated}

All of basic positions had Pay loader driver, Excavator driver, Operating plant labor, Removal foreign material, Officer, Manager, Sales and marketing, Security guard, housemate and Accountant. The number of employees for each position was depended on the plant's size. Labor Cost will increase about $4 \%$ to $6 \%$ per year with Bonus about $10 \%$ of EBIT.

\subsubsection{Inventory}

It was assumed to be first in first out method. Besides, if volume of the inventory was five times of current demand, it is assumed that inventory will be sold out at half of selling price.

\subsubsection{Location}

Location will be stay in the area the far away from natural aggregate crushing plant [21] in order to have a low competitive. However, the other factor was the land price; the RCA plant should be located in the proper area and not lead to high investment. The area of the RCA plant was about 1,000 to 2,000 Square meters depending on the plant's size in order to support the inventory and goods about 30 days. We assume the plant was found in the middle zone of Bangkok which can have a higher chance to collect demolished concrete and the cost of investment was not too high [22].

\subsubsection{Transportation}

Demolished concrete transportation was assumed to be included in buying price. Because it can see how much maximum input cost the model was still profitable. RCA transportation was assumed to be on buyer site which was the normal practice in this process.

\subsubsection{Miscellaneous}

It was assumed as certain amount depending on machine capacity.

\subsubsection{Other financial ratio}

Debt to Equity ratio was assumed to be 1.5 which is the average rate that Bank was acceptable to approve the loan. Account receivable period: normally, a customer used the payment 30 days after delivery. Account Payable turnover period: normally, contractors, demolishers collected money instantly after a trade.

\subsubsection{Other data}

Such as electricity, exchange rate and diesel fuel rate, they were based on data in year 2016 [17, 23].

\subsection{Input Parameters}

From assumption, all parameters put in model were show as in Table 2. Besides 100 ton-per-hour plant has to invest higher than 50 ton-per-hour plant 18.78 million baht or about $35.59 \%$. 
Table 2. Input parameters for starting the simulation.

\begin{tabular}{|c|c|c|c|c|c|c|c|c|c|c|}
\hline \multirow[t]{2}{*}{ Input } & \multirow[t]{2}{*}{ Unit } & \multirow{2}{*}{$\begin{array}{l}\text { Variable } \\
\text { Type - }\end{array}$} & \multicolumn{2}{|c|}{$\begin{array}{l}\text { Method 1: } 100 \text { ton/hr; } \\
\text { Constant Supply }\end{array}$} & \multicolumn{2}{|c|}{$\begin{array}{l}\text { Method 2: } 50 \text { ton/hr; } \\
\text { Constant Supply }\end{array}$} & \multicolumn{2}{|c|}{$\begin{array}{c}\text { Method 3: } 100 \\
\text { ton/hr;:Uncertain supply }\end{array}$} & \multicolumn{2}{|c|}{$\begin{array}{l}\text { Method 4: } 50 \text { ton/hr; } \\
\text { Uncertain supply }\end{array}$} \\
\hline & & & Parameter & QTY & Parameter & QTY & Parameter & QTY & Parameter & QTY \\
\hline Period & Year & Constant & 10 & - & 10 & 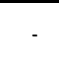 & 10 & - & 10 & - \\
\hline Demand & & & & - & & . & & $\cdot$ & & - \\
\hline Coarse RCA (>\#4) & Ton & Random & $\begin{array}{c}=\text { Output of Nachine } \\
\text { Capacity }\end{array}$ & & $\begin{array}{c}=\text { Output of Machine } \\
\text { Capacity }\end{array}$ & - & $\begin{array}{c}=\text { Ouput of Nachine } \\
\text { Capacity }\end{array}$ & - & $\begin{array}{c}=\text { Output of Machine } \\
\text { Capacity }\end{array}$ & - \\
\hline Fine $\operatorname{RCA}(<\# 4)$ & Ton & Random & 2,287 & 7 - & 2,287 & 7 - & 2,287 & . & 2,287 & - \\
\hline Growth Trend of Coarse RCA & $\%$ & Constant & - & . & - & & - & - & - & - \\
\hline Growth Trend of Fine RCA & $\%$ & Constant & $5.63 \%$ & - & $5.63 \%$ & & $5.63 \%$ & $\cdot$ & $5.63 \%$ & - \\
\hline Average Selling price & & & & - & & $\cdot$ & & $\cdot$ & & - \\
\hline Coarse RCA (>\#4) & $\mathrm{THB} / \mathrm{Ton}$ & n Random & $180,190,200$ & - & $180,190,200$ & - & $180,190,200$ & $\cdot$ & $180,190,200$ & - \\
\hline Fine $\operatorname{RCA}(<\# 4)$ & $\mathrm{THB} / \mathrm{Ton}$ & n Random & $80,90,100$ & - & $80,90,100$ & - & $80,90,100$ & - & $80,90,100$ & - \\
\hline Growth Trend of Coarse RCA & $\%$ & Constant & - & & - & - & - & & - & - \\
\hline Growth Trend of Fine RCA & $\%$ & Constant & - & & - & - & - & & - & - \\
\hline Scrap Steel & $\mathrm{THB} / \mathrm{Ton}$ & in Constant & 5,000 & 0 & 5,000 & - & 5,000 & - & 5,000 & - \\
\hline Supply & & & & - & & - & & $\cdot$ & & - \\
\hline Demolsih Concrete & Ton & Random & $\begin{aligned}= & \text { Total Machine } \\
& \text { Capacity }\end{aligned}$ & & $\begin{array}{c}=\text { Total Machine } \\
\text { Capacity }\end{array}$ & ${ }^{\circ}$ & $32.34-38.46$ & & $32.34-38.46$ & - \\
\hline Growth Trend of Demolsih Concrete & $\%$ & Constant & - & - & - & - & $\begin{array}{c}\text { AVG 1.32\%, STDEV } \\
5 \%\end{array}$ & . & AVG 1.32\%, STDEV 5\% & . \\
\hline Material Cost (Average Buying price in & cluding tri & ransportation) & & - & & . & & $\cdot$ & & . \\
\hline Demolsih Concrete & $\mathrm{THB} / \mathrm{Ton}$ & in Constant & $\begin{array}{c}0,10,20, \ldots \text {...nit } \\
\text { unprofitable }\end{array}$ & & $\begin{array}{l}0,10,20, \ldots \text { unti } \\
\text { unprofitable }\end{array}$ & ${ }^{-}$ & $\begin{array}{c}0,10,20, \ldots \text { unti } \\
\text { unprofitable }\end{array}$ & & $0,10,20, \ldots$...nti unprofitable & . \\
\hline Growth Trend of Demolsih Concrete & $\%$ & Constant & - & - & - & - & - & - & - & - \\
\hline Machine & & & & & & - & & & & - \\
\hline Capacity & Ton/hr & Random & 95 to 100 & - & 28.5 to 30 & & $\begin{aligned}= & \text { Supply, but not over } \\
& \text { machine capacity }\end{aligned}$ & & $\begin{array}{c}\text { = Supply, but not over } \\
\text { machine capacity }\end{array}$ & $\cdot$ \\
\hline The operating time & & & & . & & - & & - & & . \\
\hline Hour & $\mathrm{Hr} / \mathrm{day}$ & Constant & 8 & - & 8 & . & 8 & - & 8 & . \\
\hline Day & $\mathrm{Day} / \mathrm{Mth}$ & h Constant & 26 & - & 26 & & 26 & - & 26 & \\
\hline RCA Output & & & & - & & & & $\cdot$ & & \\
\hline Coarse RCA & $\%$ & Random & $67.00 \%-85.00 \%$ & - & $67.00 \%-85.00 \%$ & 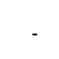 & $67.00 \%-85.00 \%$ & - & $67.00 \%-85.00 \%$ & - \\
\hline Fine RCA & $\%$ & Random & $14.80 \%-32 ., 00 \%$ & - & $14.80 \%-32.90 \%$ & - & $14.80 \%-32 ., 90 \%$ & - & $14.80 \%-32.90 \%$ & . \\
\hline Scrap Steel & $\%$ & Random & $0.10 \%-0.20 \%$ & . & $0.10 \%-0.20 \%$ & & $0.10 \%-0.20 \%$ & . & $0.10 \%-0.20 \%$ & \\
\hline
\end{tabular}




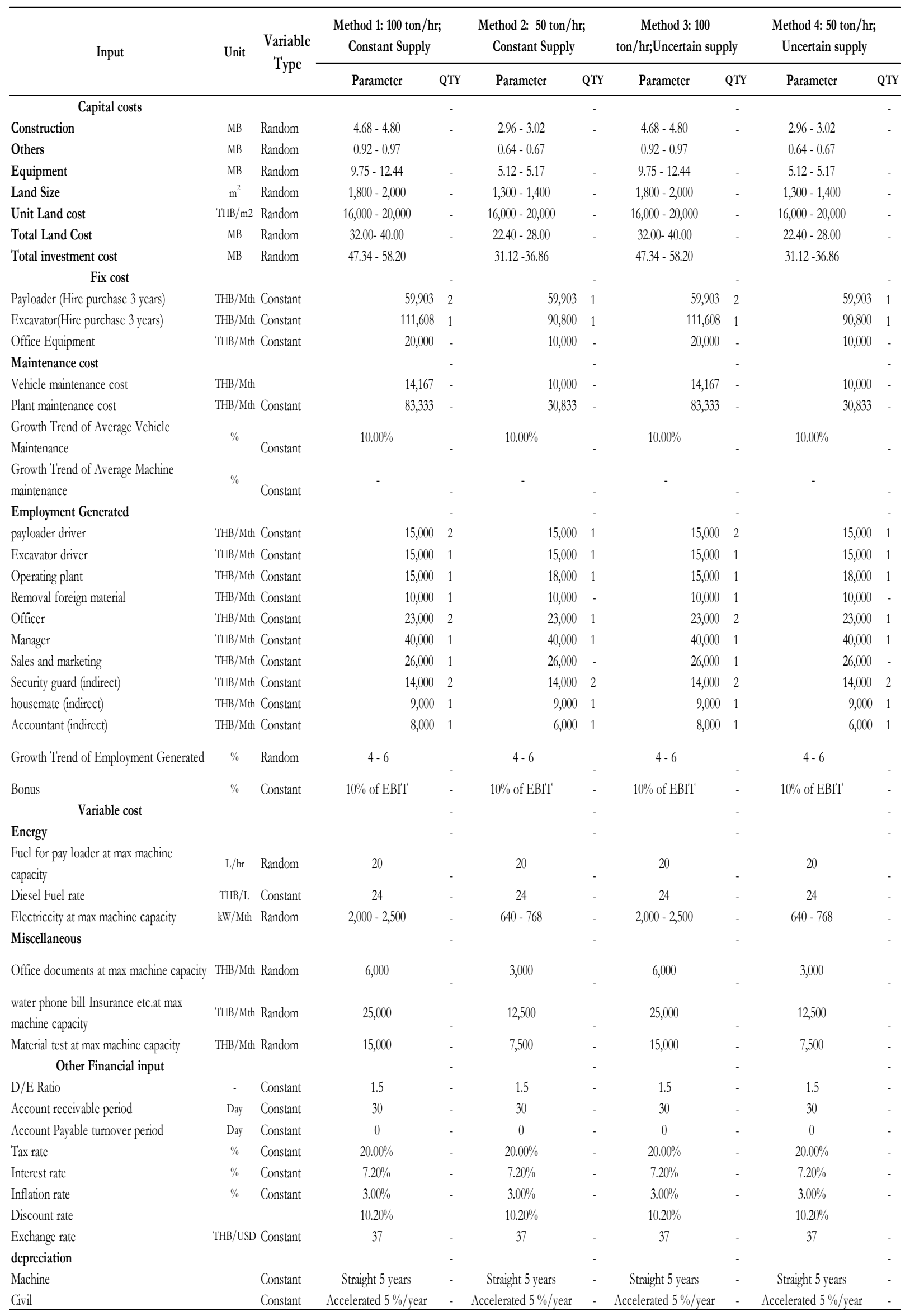




\subsection{Model Development}

In this research tried to put the model more complicated by adding specific data of input of random variables and go with Monte Carlo 5 steps [24].

Step 1: Create a parametric model, $y=f\left(x_{1}, x_{2}, \ldots, x_{q}\right)$.

- The model will calculate as the step of net profit computation.

- The result of each row of calculation represents one month result.

Therefore, there are 120 rows according to the 10-year-period.

- The results are brought to create Income Statement, Cash flow statement and Balance Sheet.

- Finally, 1.Payback period, 2. EBITDA per year/Initial investment 3.Profitability Index, 4.Internal rate of return (IRR), 5. Average Net profit and 6. Average unit cost, are computed from 3 financial tables [25-27].

Step 2: Generate a set of random inputs, $\mathrm{xi}_{1}, \mathrm{xi}_{2}, \ldots, \mathrm{xi}_{\mathrm{q}}$.

- Each Xiq is from Table 2.

Step 3: Evaluate the model and store the results as yi.

- Store the 6 results; those are called 1 set of data.

Step 4: Repeat steps 2 and 3 for $i=1$ to $n$.

- $\mathrm{n}$ is set at 100 times per results.

Step 5: Analyze the results

- After completion for one size of RCA plant in the first condition, a model will have set of data at selling price $0,10,20, \ldots, 100$ baht per ton and buying price 180-80,190-90, 200-100 baht per ton; in total 33 sets of data were collected. (180 was selling price for coarse RCA and 80 was selling price for Fine RCA. Other couples are the same principle).

- Then, only set of data at buying price 0 baht per ton and at Profitability Index about 1 will be used for analysis. Because buying price 0 baht can show the best performance of each model and Profitability Index about 1 can show the highest buying price that a model was still profitable.

- After that, the other sizes and conditions will be calculated until obtaining all results from all models.

- Finally, those data will be compared and find out advantages and disadvantages, and bring the best model to do a sensitivity analysis.

\begin{tabular}{|c|c|c|}
\hline $\begin{array}{c}\text { Input } \\
\text { parameters } \\
\text { from Table } 2\end{array}$ & $\begin{array}{c}\text { Process } \\
\text { Financial calculation } \\
\text { by Monte Carlo } \\
\text { simulation }\end{array}$ & \begin{tabular}{ll} 
& \multicolumn{1}{c}{ Output } \\
- & AVG Unit cost \\
- & Income Statement \\
- & Cash flow Statement \\
- & Balance Sheet \\
- & Financial Ratios
\end{tabular} \\
\hline
\end{tabular}

Fig. 8. Overall process for the model development. 


\begin{tabular}{|r|c|c|c|}
\hline & $\mathbf{1 8 0}$ & $\mathbf{1 9 0}$ & $\mathbf{2 0 0}$ \\
\hline $\mathbf{0}$ & 1 & 2 & 3 \\
\hline $\mathbf{1 0}$ & 4 & 5 & 6 \\
\hline $\mathbf{2 0}$ & $\mathbf{P I 1 7}$ & 8 & 9 \\
\hline $\mathbf{3 0}$ & 10 & 11 & 12 \\
\hline $\mathbf{4 0}$ & 13 & PI114 & 15 \\
\hline $\mathbf{5 0}$ & 16 & 17 & 18 \\
\hline $\mathbf{6 0}$ & 19 & 20 & PI121 \\
\hline $\mathbf{7 0}$ & 22 & 23 & 24 \\
\hline $\mathbf{8 0}$ & 25 & 26 & 27 \\
\hline $\mathbf{9 0}$ & 28 & 29 & 30 \\
\hline $\mathbf{1 0 0}$ & 31 & 32 & 33 \\
\hline
\end{tabular}

Fig. 9. Example of data collecting and data picking for analysis

\subsection{Sensitivity Analysis}

Sensitivity analysis will be based on the situation which may be possible to happen.

Condition 1: Cut indirect labor which means that the plant is found in the ready mix plant area which can share indirect labor.

Condition 2: Decrease 10 percent of all labor costs. This is possible thanks to the labor costs in the model that are set at a good rate.

Condition 3: Benefit from 0 percent tax in first 5 years thanks to The Board of Investment of Thailand (BOI) that may provide for the environmental project.

Condition 4: Decrease 10 percent of investment cost. This is possible thanks to the office costs in the model that are set at a standard office. In fact, it can be substituted by Container office. Besides, the land cost may be purchase at the lower price than assumption.

Condition 5: Reduce the percent of Coarse RCA output in order to see the relation between percent of RCA output and Revenue due to the fact that coarse RCA and fine RCA can be sold at different price. The lower Coarse RCA output leads the lower revenue.

\subsection{Limitation}

In case the model showed the negative net profit, the results of many value will be tend to error due to the fact that cash flow is negative and the model is not assumed to borrow more money. 


\section{Results and Discussion}

\subsection{Results}

First: 100-ton-per-hour constant supplied plant.

From Table 3, all measures of all selling prices showed impressive result. The higher selling price it was set, the higher return on investment it was. Besides, Payback periods were lower than 2.5 years which is not too long for an environmental project and does not bear a risk of technological change.

Table 3. Result of 100-ton-per-hour constant supplied plant.

\begin{tabular}{lrrrrrr}
\hline Selling price (THB/ton) & \multicolumn{2}{c}{$180-80$} & \multicolumn{2}{c}{$190-90$} & \multicolumn{2}{c}{$200-100$} \\
\hline Average buying price = & 0 & - & 0 & - & 0 & - \\
PI > 1,Buying price=(THB/ton) & - & 60 & - & 70 & - & 80 \\
\hline PI & 2.23 & 1.03 & 2.42 & 1.01 & 2.6 & 1.00 \\
Payback period (year) & 2.53 & 5.41 & 2.24 & 5.57 & 2.18 & 5.62 \\
IRR & $33.71 \%$ & $10.84 \%$ & $36.93 \%$ & $10.49 \%$ & $39.86 \%$ & $10.22 \%$ \\
\% EBITDA & $46.14 \%$ & $21.43 \%$ & $50.16 \%$ & $21.22 \%$ & $53.86 \%$ & $21.10 \%$ \\
Average unit cost (THB/ton) & 47.81 & 104.24 & 48.44 & 114.23 & 48.94 & 124.3 \\
Average Net Income (MB) & 18.02 & 7.14 & 19.7 & 7.06 & 21.34 & 8.76 \\
Minimum supply & $95 \%$ & $95 \%$ & $95 \%$ & $95 \%$ & $95 \%$ & $95 \%$ \\
Maximum supply & $100 \%$ & $100 \%$ & $100 \%$ & $100 \%$ & $100 \%$ & $100 \%$ \\
\hline
\end{tabular}

Second: 50-ton-per-hour constant supplied plant.

From Table 4, all measures of all selling prices showed impressive result. The higher selling price it was set, the higher return on investment it was. Payback periods were about 3 to 3.2 years which is not too long for an environmental project.

At Profitability index about 1 of both first and second models, Payback periods were higher than 5 years even other measures were in the acceptable values. Therefore, it is depended on a company's strategy whether to accept it or not. Concerning to the environmental issue, it may be acceptable.

Table 4. Result of 50-ton-per-hour constant supplied plant.

\begin{tabular}{lrrrrrr}
\hline Selling price (THB/ton) & \multicolumn{2}{c}{$180-80$} & \multicolumn{2}{c}{$190-90$} & \multicolumn{2}{r}{$200-100$} \\
\hline Average buying price = & 0 & - & 0 & - & 0 & - \\
PI > 1,Buying price=(THB/ton) & - & 45 & - & 55 & - & 65 \\
\hline PI & 1.71 & 1.02 & 1.87 & 1.00 & 2.01 & 1.00 \\
Payback period (year) & 3.19 & 5.54 & 3.11 & 5.57 & 3.01 & 5.59 \\
IRR & $24.86 \%$ & $10.49 \%$ & $27.44 \%$ & $10.26 \%$ & $29.96 \%$ & $10.25 \%$ \\
\% EBITDA & $35.49 \%$ & $20.75 \%$ & $38.48 \%$ & $20.57 \%$ & $41.40 \%$ & $20.64 \%$ \\
Average unit cost (THB/ton) & 55.51 & 97.29 & 56.25 & 107.3 & 56.97 & 117.27 \\
Average Net Income (MB) & 8.75 & 4.6 & 9.64 & 4.58 & 10.53 & 4.56 \\
Minimum supply & $95 \%$ & $95 \%$ & $95 \%$ & $95 \%$ & $95 \%$ & $95 \%$ \\
Maximum supply & $100 \%$ & $100 \%$ & $100 \%$ & $100 \%$ & $100 \%$ & $100 \%$ \\
\hline
\end{tabular}

Third: 100-ton-per-hour uncertain supplied plant

From Table 5, Profitability indexes were lower than 1, and besides, almost all results were malfunction due to the limitation of the negative net profit which the model did not set to invest more money in case it showed the negative profits; therefore, there were no cash for continued business, and the reason caused 
this was from the mismatch of supply ( 35 to 42 ton per hour) and machine capacity (100 ton per hour); therefore, revenue cannot fulfill the fix cost expense.

Table 5. Result of 100-ton-per-hour uncertain supplied plant.

\begin{tabular}{|c|c|c|c|c|c|c|}
\hline \multirow{3}{*}{$\begin{array}{l}\text { selling price }(\mathrm{THB} / \text { ton }) \\
\text { Average buying price }=0 \\
\mathrm{PI}>1, \text { Buying } \\
\text { price }=(\mathrm{THB} / \text { ton })\end{array}$} & \multicolumn{2}{|c|}{$180-80$} & \multicolumn{2}{|c|}{$190-90$} & \multicolumn{2}{|c|}{$200-100$} \\
\hline & 0 & - & 0 & - & 0 & - \\
\hline & & $\begin{array}{c}\text { No } \\
\text { Answer }\end{array}$ & - & $\begin{array}{c}\text { No } \\
\text { Answer }\end{array}$ & - & $\begin{array}{l}\text { No } \\
\text { Answer }\end{array}$ \\
\hline PI & 0.67 & & 0.74 & & 0.82 & \\
\hline Payback period (year) & 8.6 & & 7.89 & & 7.06 & \\
\hline IRR & $2.02 \%$ & & $3.68 \%$ & & $5.85 \%$ & \\
\hline & 13.26 & & 14.54 & & 16.33 & \\
\hline$\%$ EBITDA & $\%$ & & $\%$ & & $\%$ & \\
\hline unit cost (THB/ton) & 71.79 & & 72.28 & & 72.53 & \\
\hline average Net Income (MB) & 3.45 & & 4.07 & & 4.83 & \\
\hline Minimum supply & $35 \%$ & & $35 \%$ & & $35 \%$ & \\
\hline Maximum supply & $42 \%$ & & $41 \%$ & & $42 \%$ & \\
\hline
\end{tabular}

Fourth: 50-ton-per-hour uncertain supplied plant

From Table 6, all measures of all selling prices showed fair result. The higher selling price it was set, the higher return on investment it was.

At buying price 0 baht per ton, profitability indexes were higher than 1.23 to 1.47 which. Payback periods were about 4 to 4.67 years which may be acceptable because of an environmental project.

Table 6. Result of 50-ton-per-hour uncertain supplied plant.

\begin{tabular}{lcrrrrr}
\hline selling price (THB/ton) & \multicolumn{2}{c}{$180-80$} & \multicolumn{2}{c}{$190-90$} & \multicolumn{2}{c}{$200-100$} \\
\hline Average buying price = & 0 & & 0 & & 0 & \\
PI > 1,Buying price=(THB/ton) & & 20 & & 30 & - & 40 \\
\hline PI & 1.23 & 1.00 & 1.37 & 1.00 & 1.47 & 0.98 \\
Payback period (year) & 4.67 & 5.79 & 4.27 & 5.83 & 4.05 & 5.91 \\
IRR & $14.90 \%$ & $9.96 \%$ & $17.76 \%$ & $9.98 \%$ & $19.58 \%$ & $9.35 \%$ \\
$\%$ EBITDA & $25.10 \%$ & $20.33 \%$ & $28.35 \%$ & $20.46 \%$ & $30.30 \%$ & $20.13 \%$ \\
Average unit cost (THB/ton) & 61.64 & 80.28 & 61.95 & 90.05 & 62.89 & 100.44 \\
Average Net Income (MB) & 5.87 & 4.45 & 6.75 & 4.5 & 7.36 & 4.46 \\
Minimum supply & $70 \%$ & $70 \%$ & $70 \%$ & $69 \%$ & $69 \%$ & $69 \%$ \\
Maximum supply & $82 \%$ & $83 \%$ & $83 \%$ & $81 \%$ & $82 \%$ & $82 \%$ \\
\hline
\end{tabular}




\subsection{Model Comparison}

Besides, the model can provide the probability of the trend which also can show in Histogram.

\begin{tabular}{|c|c|c|c|c|c|c|c|}
\hline $\begin{array}{c}\text { Payback } \\
\text { period } \\
\text { range }\end{array}$ & $\begin{array}{c}\text { Method } 1 \\
100 \text { ton/hr; } \\
\text { Constant } \\
\text { Supply }\end{array}$ & $\begin{array}{c}\text { Method } 2 \\
50 \text { ton/hr; } \\
\text { Constant } \\
\text { Supply }\end{array}$ & $\begin{array}{c}\text { Method } 3 \\
100 \text { ton/hr; } \\
\text { Uncertain } \\
\text { supply }\end{array}$ & $\begin{array}{c}\text { Method } 4 \\
50 \text { ton/hr; } \\
\text { Uncertain } \\
\text { supply }\end{array}$ & \multicolumn{2}{|c|}{120} & \multirow{2}{*}{$\begin{array}{l}\text { Method } 1 \\
100 \text { ton/hr; } \\
\text { Constant } \\
\text { Supply }\end{array}$} \\
\hline 1 & 0 & 0 & 0 & 0 & 100 & & \\
\hline 1.5 & 0 & 0 & 0 & 0 & \multirow{3}{*}{80} & 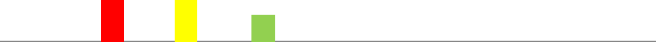 & \multirow{5}{*}{$\begin{array}{l}\text { Method } 2 \\
50 \text { ton/hr; } \\
\text { Constant } \\
\text { Supply }\end{array}$} \\
\hline 2 & 0 & 0 & 0 & 0 & & & \\
\hline 2.5 & 100 & 6 & 0 & 0 & & & \\
\hline 3 & 0 & 0 & 0 & 0 & \multirow[t]{2}{*}{60} & & \\
\hline 3.5 & 0 & 94 & 0 & 9 & & & \\
\hline 4 & 0 & 0 & 0 & 0 & \multirow{3}{*}{40} & & \multirow{4}{*}{$\begin{array}{l}\text { Method } 3 \\
100 \text { ton/hr; } \\
\text { Uncertain } \\
\text { supply }\end{array}$} \\
\hline 4.5 & 0 & 0 & 0 & 85 & & & \\
\hline 5 & 0 & 0 & 0 & 0 & & & \\
\hline 5.5 & 0 & 0 & 1 & 6 & \multirow[t]{3}{*}{20} & & \\
\hline 6 & 0 & 0 & 0 & 0 & & & \multirow{5}{*}{$\begin{array}{l}\text { Method } 4 \\
50 \text { ton/hr; } \\
\text { Uncertain } \\
\text { supply }\end{array}$} \\
\hline 6.5 & 0 & 0 & 23 & 0 & & 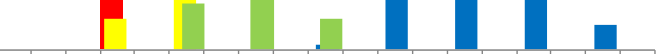 & \\
\hline 7 & 0 & 0 & 0 & 0 & \multirow[t]{2}{*}{0} & $\begin{array}{lllllllllllllllllll}1 & 1.5 & 2 & 2.5 & 3 & 3.5 & 4 & 4.5 & 5 & 5.5 & 6 & 6.5 & 7 & 7.5 & 8 & 8.5 & 9 & 9.5 & 10\end{array}$ & \\
\hline 7.5 & 0 & 0 & 52 & 0 & & & \\
\hline 8 & 0 & 0 & 0 & 0 & & & \\
\hline 8.5 & 0 & 0 & 19 & 0 & & & \\
\hline 9 & 0 & 0 & 0 & 0 & & & \\
\hline 9.5 & 0 & 0 & 5 & 0 & & & \\
\hline 10 & 0 & 0 & 0 & 0 & & & \\
\hline Average & 2.18 & 3.01 & 7.06 & 4.05 & & & \\
\hline
\end{tabular}

Fig. 10. Histogram point of view comparing payback period of 4 methods at selling price $200-100$ baht/ton.

From Fig. 10, Method 1, it was 100 percent that the payback periods were between 2 to 2.5 years. Method 2, it was 94 percent that the payback periods were between 3 to 3.5 years. Method 3, it was 52 percent that the payback periods were between 7 to 7.5 years. Method 4, it was 85 percent that the payback periods were between 4 to 4.5 years. Besides, the average value of payback period of each method was conformed to the majority population of its data.

From Table 7, the best alternatives of each model were compared together in quantitative term. Almost all methods were survived except the method 3 due to the supply deficiency. Therefore, what is the enough supply to operate both models? This research did a simulation both RCA plant sizes to find out relation between buying prices and supplied volume that how much of supplied volume need to still generate Profitability Index about 1 which the result was shown in Fig. 11. 
Table 7. Result comparison of 4 methods at selling price $200-100 \mathrm{baht} / \mathrm{ton}$.

\begin{tabular}{|c|c|c|c|c|c|c|}
\hline $\begin{array}{c}\text { At selling price } \\
\text { (THB/ton) } 200- \\
100\end{array}$ & $\begin{array}{l}\text { Method } 1 \\
100 \text { ton/hr; } \\
\text { Constant } \\
\text { Supply }\end{array}$ & $\begin{array}{c}\text { Method } 2 \\
50 \text { ton } / \mathrm{hr} \\
\text { Constant } \\
\text { Supply }\end{array}$ & $\begin{array}{c}\text { Method } 3 \\
100 \\
\text { ton } / \mathrm{hr} \\
\text { Uncertain } \\
\text { supply }\end{array}$ & $\begin{array}{l}\text { Method } 4 \\
50 \text { ton/hr; } \\
\text { Uncertain } \\
\text { supply }\end{array}$ & $\begin{array}{l}\text { Comparison } \\
\text { Method } 1 \text { and } \\
\text { Method } 2\end{array}$ & $\begin{array}{c}\text { Comparison } \\
\text { Method } 2 \\
\text { and Method } \\
4\end{array}$ \\
\hline $\begin{array}{l}\text { Average } \\
\text { investment (MB) }\end{array}$ & 52.77 & 33.99 & 52.77 & 33.99 & $35.59 \%$ & $0.00 \%$ \\
\hline \multicolumn{7}{|c|}{ At average buying price $=0$} \\
\hline - PI & 2.6 & 2.01 & 0.82 & 1.47 & $22.31 \%$ & $27.23 \%$ \\
\hline $\begin{array}{l}\text { - Payback period } \\
\text { (year) }\end{array}$ & 2.18 & 3.01 & 7.06 & 4.05 & $-37.16 \%$ & $-35.45 \%$ \\
\hline - IRR & $39.86 \%$ & $29.96 \%$ & $5.85 \%$ & $19.58 \%$ & $24.84 \%$ & $34.65 \%$ \\
\hline - \% EBITDA & $53.86 \%$ & $41.40 \%$ & $16.33 \%$ & $30.30 \%$ & $23.13 \%$ & $26.81 \%$ \\
\hline $\begin{array}{l}\text { - Average Net } \\
\text { Income (MB) } \\
\text { At PI } \approx \mathbf{1}\end{array}$ & 21.34 & 10.53 & 4.83 & 7.36 & $50.66 \%$ & $30.10 \%$ \\
\hline $\begin{array}{l}\text { - Maximum } \\
\text { buying price } \\
\text { (THB/ton) }\end{array}$ & 80 & 65 & $\mathrm{~N} / \mathrm{A}$ & 40 & $18.75 \%$ & $38.46 \%$ \\
\hline $\begin{array}{l}\text { - Payback period } \\
\text { (year) }\end{array}$ & 5.62 & 5.5 & $\mathrm{~N} / \mathrm{A}$ & 5.91 & $0.53 \%$ & $-5.72 \%$ \\
\hline - IRR & $10.22 \%$ & $10.25 \%$ & $\mathrm{~N} / \mathrm{A}$ & $9.35 \%$ & $-0.29 \%$ & $8.78 \%$ \\
\hline - \% EBITDA & $21.10 \%$ & $20.64 \%$ & $\mathrm{~N} / \mathrm{A}$ & $20.13 \%$ & $2.18 \%$ & $2.47 \%$ \\
\hline $\begin{array}{l}\text { - Average Net } \\
\text { Income (MB) }\end{array}$ & 8.76 & 4.56 & $\mathrm{~N} / \mathrm{A}$ & 4.46 & $47.95 \%$ & $2.19 \%$ \\
\hline
\end{tabular}

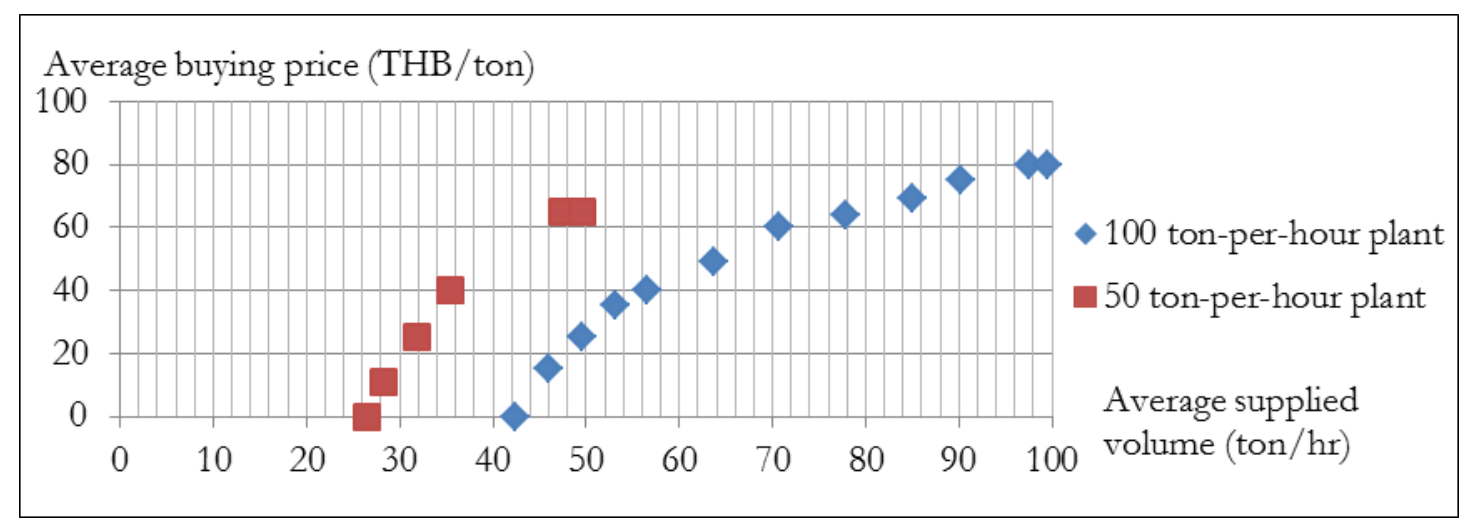

Fig. 11 Average buying prices versus supplied volume at profitability about 1.

Finally, both models were compared the advantages and disadvantages in Table 8 . 
Table 8. Advantages and disadvantages between 100 ton-per-hour plant and 50 ton-per-hour plant.

\begin{tabular}{|c|c|c|}
\hline Model & Advantages & Disadvantages \\
\hline \multirow[t]{4}{*}{$\begin{array}{l}\text { 100-ton- } \\
\text { per-hour } \\
\text { plant }\end{array}$} & $\begin{array}{l}\text { - Suppose a model can reach supply to the } \\
\text { machine capacity, }\end{array}$ & $\begin{array}{l}\text { - The model is not ready for Bangkok due to } \\
\text { supply deficiency according to the } \\
\text { assumption }\end{array}$ \\
\hline & $\begin{array}{l}\text { Showing the best performance which has } \\
\text { short Payback period. }\end{array}$ & $\begin{array}{l}\text { - Higher risk to loss due to high fix cost } \\
\text { bearing; }\end{array}$ \\
\hline & $\begin{array}{l}\text { Can accept the highest maximum buying } \\
\text { price. }\end{array}$ & $\begin{array}{l}\text { - Can accept lower average buying price at } \\
\text { the same average supplied volume. }\end{array}$ \\
\hline & $\begin{array}{l}\text { Obtain double profit; meanwhile } \\
\text { investment cost is higher than } 50 \text {-ton-per- } \\
\text { hour plant } 35.59 \%\end{array}$ & $\begin{array}{l}\text { - Need more area to set up a plant which may } \\
\text { be difficult to find in City }\end{array}$ \\
\hline \multirow[t]{3}{*}{$\begin{array}{l}\text { 50-ton- } \\
\text { per-hour } \\
\text { plant }\end{array}$} & $\begin{array}{l}\text { Lower investment, but still get acceptable } \\
\text { results both constant and uncertain supply }\end{array}$ & $\begin{array}{l}\text { - Higher unit fix cost to operate a plant; } \\
\text { machine capacity is half of } 100 \text { ton-per-hour } \\
\text { plant, but its fix cost is reduced only } 44.5 \%\end{array}$ \\
\hline & $\begin{array}{l}\text {-Can accept higher average buying price at } \\
\text { the same average supplied volume thanks } \\
\text { to the lower fix cost. } \\
\text { - More suitable for current supply in } \\
\text { Bangkok according to the assumption }\end{array}$ & $\begin{array}{l}\text { - Poorer results than } 100 \text { ton-per-hour plant } \\
\text { at maximum machine capacity. }\end{array}$ \\
\hline & - Need lower area to set up a plant & \\
\hline
\end{tabular}

Considering into all methods, the method 4 the 50 ton-per-hour plant was the best alternative according to the assumption. Therefore, it was brought to do sensitivity analysis. In addition, Table 9, Table 10, and Table 11 were examples of financial statement outputs from the simulation of 50 ton-per-hour plant.

Table 9. Income statement: 50 ton-per-hour plant under uncertain supply.

\begin{tabular}{lrrrrrrrrrr}
\hline Income Statement (year) & \multicolumn{1}{c}{ Fistt } & Second & Third & \multicolumn{1}{l}{ Forth } & Fifth & Sixth & Seventh & Eighth & Nineth & Tenth \\
\hline Revenue & 16.28 & 17.80 & 17.80 & 17.47 & 16.88 & 17.77 & 17.79 & 17.80 & 18.43 & 17.27 \\
Total COGS & 6.46 & 6.83 & 6.89 & 5.25 & 5.23 & 5.56 & 5.67 & 5.80 & 5.99 & 5.91 \\
\hline Gross Income & 9.83 & 10.97 & 10.91 & 12.21 & 11.65 & 12.22 & 12.13 & 12.00 & 12.44 & 11.36 \\
Operating Expense & 2.12 & 2.18 & 2.20 & 2.27 & 2.29 & 1.20 & 1.23 & 1.26 & 1.31 & 1.32 \\
\hline Operating Income & 7.71 & 8.79 & 8.70 & 9.94 & 9.36 & 11.02 & 10.90 & 10.74 & 11.13 & 10.04 \\
Interest Expense & 1.50 & 1.39 & 1.27 & 0.99 & 0.57 & 0.12 & - & - & - & - \\
\hline EBT & 6.20 & 7.40 & 7.44 & 8.95 & 8.80 & 10.89 & 10.90 & 10.74 & 11.13 & 10.04 \\
TAX & 1.24 & 1.48 & 1.49 & 1.79 & 1.76 & 2.18 & 2.18 & 2.15 & 2.23 & 2.01 \\
\hline Net Income & 4.96 & 5.92 & 5.95 & 7.16 & 7.04 & 8.71 & 8.72 & 8.59 & 8.91 & 8.04 \\
\hline
\end{tabular}


Table 10. Cash flow statement: 50 ton-per-hour plant under uncertain supply.

\begin{tabular}{|c|c|c|c|c|c|c|c|c|c|c|}
\hline Cash flow statement (year & Fisrt & Second & Third & Forth & Fifth & Sixth & Seventh & Eighth & Nineth & Tenth \\
\hline \multicolumn{11}{|c|}{ Operating Activieties } \\
\hline Cash generated from sales & 14.93 & 15.88 & 15.57 & 14.49 & 14.81 & 14.58 & 15.70 & 15.94 & 16.16 & 16.54 \\
\hline Material cost & - & - & - & - & - & - & - & - & - & - \\
\hline DirectCost & -6.46 & -6.73 & -6.73 & $-\quad 4.89$ & $-\quad 5.08$ & $-\quad 5.21$ & $-\quad 5.53$ & - 5.73 & -5.88 & -6.07 \\
\hline Indirect Cost & - $\quad 0.80$ & $-\quad 0.85$ & - $\quad 0.87$ & - $\quad 0.92$ & - 0.96 & - 1.01 & - $\quad 1.07$ & - $\quad 1.11$ & $-\quad 1.15$ & - 1.19 \\
\hline Tax & - $\quad 1.24$ & $-\quad 1.41$ & -1.36 & -1.53 & -1.63 & -1.86 & $-\quad 2.07$ & -2.08 & -2.09 & -2.13 \\
\hline Total Operating Activities & 6.43 & 8.25 & 8.05 & 8.57 & 8.46 & 7.84 & 8.35 & 8.45 & 8.49 & 8.62 \\
\hline \multicolumn{11}{|l|}{ Financing Activieties } \\
\hline Equity & 14.47 & & & & & & & & & \\
\hline Debt & 21.70 & & & & & & & & & \\
\hline Repayment to Bank & -1.54 & $-\quad 1.65$ & -1.78 & $-\quad 5.05$ & $-\quad 5.65$ & -6.04 & & & & \\
\hline Interest expense & $-\quad 1.51$ & -1.40 & -1.28 & -1.04 & - 0.66 & - 0.23 & & & & \\
\hline Total Financing Activietie & 33.12 & $-\quad 3.05$ & $-\quad 3.05$ & $-\quad 6.09$ & -6.30 & -6.27 & & & & \\
\hline \multicolumn{11}{|l|}{ Investing Activities } \\
\hline Installation plant & - $\quad 0.65$ & & & & & & & & & \\
\hline Equipment & - $\quad 5.17$ & & & & & & & & & \\
\hline Land & -27.02 & & & & & & & & & \\
\hline Building & $-\quad 3.02$ & & & & & & & & & \\
\hline \multicolumn{11}{|c|}{ Total Investing Activities - 35.86} \\
\hline Total Cash Flow & 3.69 & 5.20 & 5.00 & 2.48 & 2.16 & 1.57 & 8.35 & 8.45 & 8.49 & 8.62 \\
\hline
\end{tabular}


Table 11. Balance Sheet: 50 ton-per-hour plant under uncertain supply.

\begin{tabular}{|c|c|c|c|c|c|c|c|c|c|c|}
\hline Balance Sheet (year) & Fisrt & Second & Third & Forth & Fifth & Sixth & Seventh & Eighth & Nineth & Tenth \\
\hline \multicolumn{11}{|l|}{ Asset } \\
\hline \multicolumn{11}{|l|}{ Current Asset } \\
\hline Cash & 3.45 & 8.33 & 13.75 & 17.43 & 21.02 & 28.56 & 39.65 & 50.45 & 60.77 & 70.23 \\
\hline Account Receivable & 1.33 & 1.41 & 1.50 & 1.72 & 1.79 & 1.68 & 1.80 & 1.76 & 1.71 & 1.60 \\
\hline \multicolumn{11}{|l|}{ Inventories } \\
\hline Total Current Asset & 4.78 & 9.74 & 15.25 & 19.15 & 22.81 & 30.25 & 41.45 & 52.21 & 62.48 & 71.83 \\
\hline \multicolumn{11}{|l|}{ Non-Current Asset } \\
\hline Equipment & 5.83 & 5.83 & 5.83 & 5.83 & 5.83 & 5.83 & 5.83 & 5.83 & 5.83 & 5.83 \\
\hline Land & 27.58 & 27.58 & 27.58 & 27.58 & 27.58 & 27.58 & 27.58 & 27.58 & 27.58 & 27.58 \\
\hline Building & 3.02 & 3.02 & 3.02 & 3.02 & 3.02 & 3.02 & 3.02 & 3.02 & 3.02 & 3.02 \\
\hline Depreciation Equipment & 1.17 & 2.33 & 3.50 & 4.67 & 5.84 & 5.84 & 5.84 & 5.84 & 5.85 & 5.85 \\
\hline depreciation Building & 0.15 & 0.30 & 0.45 & 0.60 & 0.75 & 0.91 & 1.06 & 1.21 & 1.36 & 1.51 \\
\hline Total Non Current Asset & 35.11 & 33.79 & 32.48 & 31.16 & 29.84 & 29.68 & 29.53 & 29.38 & 29.23 & 29.07 \\
\hline Total Asset & 39.89 & 43.53 & 47.73 & 50.31 & 52.64 & 59.93 & 70.98 & 81.58 & 91.71 & 100.90 \\
\hline \multicolumn{11}{|l|}{ Liabilities } \\
\hline \multicolumn{11}{|l|}{ Current Liabilities } \\
\hline \multicolumn{11}{|l|}{ Total Current Liabilities } \\
\hline \multicolumn{11}{|l|}{ Non-Current Liabilities } \\
\hline Loan & 20.49 & 18.81 & 17.00 & 10.53 & 2.94 & & & & & \\
\hline Total Non-Current Liabili & 20.49 & 18.81 & 17.00 & 10.53 & 2.94 & & & & & \\
\hline Total Liabilities & 20.49 & 18.81 & 17.00 & 10.53 & 2.94 & & & & & \\
\hline \multicolumn{11}{|l|}{ Equity } \\
\hline Paid-in Capital & 14.70 & 14.70 & 14.70 & 14.70 & 14.70 & 14.70 & 14.70 & 14.70 & 14.70 & 14.70 \\
\hline Retained earnings & 4.71 & 10.03 & 16.02 & 25.08 & 35.00 & 45.23 & 56.28 & 66.89 & 77.01 & 86.21 \\
\hline Total Equity & 19.40 & 24.73 & 30.72 & 39.78 & 49.70 & 59.93 & 70.98 & 81.58 & 91.71 & 100.90 \\
\hline Debt + Equity & 39.89 & 43.53 & 47.73 & 50.31 & 52.64 & 59.93 & 70.98 & 81.58 & 91.71 & 100.90 \\
\hline
\end{tabular}

\subsection{Sensitivity Analysis}

The 50 ton-per-hour plant was adjusted some parameters according to each condition. The objective is to find out the impact to Payback period reduction.

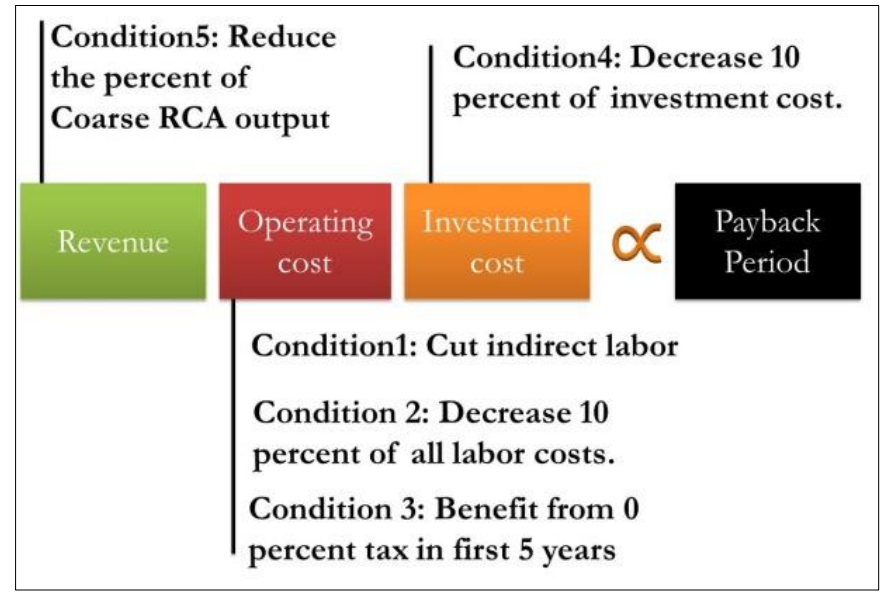

Fig. 12. Conditions of Sensitivity analysis. 


\subsubsection{Cost impact}

From 4 conditions, there were 2 groups can reduce Payback period which were total operating cost and investment cost.

In details of condition 1 to 3 , it can show a linear relationship between operating cost reduction and impact of Payback period which formula of the relation was

$$
\text { Payback period }=(-0.7144 \mathrm{x} \text { operating cost change })+0.1168
$$

From the equation, it can describe that every 1 million baht operating cost reduction per year can help the model have shorter Payback period 0.714 years.

In details of condition 4 when Interpolation was applied, we can assume that 3.421 million baht reduction can reduce Payback period -0.35 year; therefore

Every 1 million baht of investment reduction can help the model has shorter Payback period 0.102 years.

The ratio between investment reduction and cost reduction equaled 0.102:0.714 or 1: 7

Table 12. Impact of cost reduction of each condition to the financial ratio.

\begin{tabular}{|c|c|c|c|c|c|c|c|c|c|c|}
\hline Condition & \multicolumn{2}{|c|}{ Original } & \multicolumn{2}{|c|}{ Condition 1} & \multicolumn{2}{|c|}{ Condition 2} & \multicolumn{2}{|c|}{ Condition 3} & \multicolumn{2}{|c|}{ Condition 4} \\
\hline buying price $=0$ & 0 & & 0 & & 0 & & 0 & & 0 & \\
\hline $\begin{array}{l}\mathrm{PI}>1, \text { Buying } \\
\text { price }=(\mathrm{THB} / \text { ton })\end{array}$ & - & 40 & & 45 & & 40 & & 45 & & 45 \\
\hline PI & 1.47 & 0.98 & 1.54 & 1.01 & 1.50 & 1.00 & 1.58 & 0.99 & 1.60 & 1.00 \\
\hline $\begin{array}{l}\text { Payback period } \\
\text { (year) }\end{array}$ & 4.05 & 5.91 & 3.85 & 5.75 & 3.99 & 5.76 & 3.45 & 5.69 & 3.70 & 5.79 \\
\hline IRR & $19.58 \%$ & $9.35 \%$ & $20.97 \%$ & $10.72 \%$ & $20.14 \%$ & $10.07 \%$ & $22.27 \%$ & $9.92 \%$ & $22.05 \%$ & $10.05 \%$ \\
\hline$\%$ EBITDA & $30.30 \%$ & $20.13 \%$ & $31.79 \%$ & $20.72 \%$ & $31.01 \%$ & $20.55 \%$ & $29.39 \%$ & $18.90 \%$ & $33.20 \%$ & $20.66 \%$ \\
\hline $\begin{array}{l}\text { Average Net } \\
\text { Income (MB) }\end{array}$ & 7.36 & 4.46 & 7.76 & 4.60 & 7.57 & 4.77 & 7.88 & 4.44 & 7.41 & 4.18 \\
\hline
\end{tabular}

\subsubsection{Revenue impact}

Condition 5: Reduce the percent of Coarse RCA. Five simulations were computed in order to see the different impacting to the financial ratio which was shown in Table 13.

Table 13. impact of coarse RCA output to the financial ratio.

\begin{tabular}{lrrrrr}
\hline Average Coarse RCA Output (ton/hr) & $76 \%$ & $68 \%$ & $61 \%$ & $53 \%$ & $46 \%$ \\
\hline Maximum buying price which PI about 1(THB/ton) & 40 & 30 & 20 & 10 & 0 \\
Result when buying price = $\mathbf{0}$ THB/ton & & & & & \\
PI & 1.47 & 1.38 & 1.26 & 1.13 & 1.00 \\
Payback period (year) & 4.05 & 4.22 & 4.63 & 5.18 & 5.84 \\
IRR & $19.58 \%$ & $17.92 \%$ & $15.39 \%$ & $12.90 \%$ & $10.11 \%$ \\
\% EBITDA & $30.30 \%$ & $28.50 \%$ & $26.12 \%$ & $23.59 \%$ & $20.86 \%$ \\
Average Net Income (MB) & 7.36 & 6.83 & 6.15 & 5.42 & 4.60 \\
Revenue (MB) & 17.25 & 16.53 & 15.63 & 14.63 & 13.51 \\
\hline
\end{tabular}

In details of condition 5, it can show a linear relationship between percent of coarse RCA output, Revenue and Payback period. The formulas of the relation were

Revenue $=(12.487 \mathrm{x}$ coarse RCA output $)+7.917$

Payback period $=(-6.0226 \times$ coarse RCA output $)+8.444$ 
Payback period $=(-0.488 \times$ revenue $)+12.35$

From the equation, it can describe that every 1 million baht of revenue can impact to the Payback period 0.488 year.

\section{Conclusion and Recommendations}

\subsection{Conclusion}

A big RCA plant (100 ton per hour, 52.77 million baht investment cost) was the best model because of shortest payback period (2.18 year), Highest Profitability index (2.6), Highest IRR (39.86\%) and Highest net profit (21.34 million baht) at buying price 0 baht per ton and selling price $200-100$ baht per ton. Besides, it could accept maximum buying price to 80 baht per ton which leaded Profitability index about 1 . However, a big RCA plant cannot survive under the uncertain supply as assumption (32.34 to 38.46 ton per hour) due to the profitability index below than 1 . Nevertheless, to help the big RCA plant survive with Profitability Index about 1, supplied volume should have at least 42.5 ton per hour and buying price 0 baht ton. Another disadvantage was the fact that a big RCA plant needed larger area (2,000 square meters) to set up which may be difficult to find area in a city of Bangkok, meanwhile, a small plant needed smaller area $(1,400$ square meters).

A small RCA plant (50 ton per hour, 33.99 million baht investment cost) also showed good results but less performance than a big RCA plant. At buying price 0 baht per ton, Payback period was 3.01 years, Profitability index was 2.01, IRR 29.96\% and net profit was 10.53 million baht. Besides, it could accept maximum buying price to 65 baht per ton. In performance term, the disadvantage was that it had a higher unit fix cost to operate a plant; because machine capacity was half of a big RCA plant, but its fix cost was reduced only $44.5 \%$. However, the other advantage of a small RCA plant was that it could survive under the uncertain supply as assumption (32.34 to 38.46 ton per hour) with acceptable results. At buying price 0 baht per ton, Payback period was 4.05 years, Profitability index was 1.47 and IRR $19.58 \%$. Besides, it could accept maximum buying price to 40 baht per ton to make Profitability index about 1 . However, a small RCA plant cannot survive when supplied volume was lower than 28 baht per ton.

Moreover, Both RCA plants had similar characters.

- The higher supplied volume, the higher buying price it could accept.

- Stepping up selling price 10 baht per ton could accept higher buying price 10 baht per ton directly.

- From constant supply, both RCA plants showed the similar results when Profitability index about 1 at Payback period about 5.55 and IRR about 10\% except the capable of purchasing demolished concrete and net profit.

Finally, a small RCA plant was selected to be the proper plant for Bangkok under the uncertain supplied volume. The sensitivity analysis showed the relation among operating cost, investment cost and revenue impacting to the Payback period. In term of cost, in the same amount of cost reduction, change of operating cost could impact to Payback period higher than about 7 times to change of investment cost. In term of revenue, every 1\% coarse RCA output change could impact to the revenue 0.124 million baht, and impact to the Payback period 0.06 year; therefore, every 1 million baht of revenue could impact to the Payback period 0.488 year.

In term of simulation, the model was built to have ability to show all of financial perspectives depending on investor point of view. Besides, by allowing to using random parameters, it made the model see a trend which helps investors analyze in another dimension. For example, in case we only do constant parameters, investing a big plant for reality may cause the investment failed due to lack of supplied volume.

\subsection{Recommendations}

Even though RCA is new for Thailand, it is a new opportunity to add value to the construction chain. The investor of RCA plant obtains profit from RCA business, the constructor gets the lower price of aggregate and it is a sustainable development for environment and besides this research did a simulation to proof that the RCA plant in Bangkok can make a profit. The small RCA plant was improved by sensitivity combination. However, there are many ways to improve the RCA business. For example, 
- As a big RCA plant is the best performance but due to deficiency supply causes it cannot do in Bangkok now. In fact, the demolished concrete is higher enough to run a big RCA plant, but owning to the dispersion of occurrence which makes the supplied volume low. If there is the system to ensure supplied volume of demolished concrete, a big RCA plant is possible to set up.

- The RCA business model is related to ready mix concrete plant. If a ready mix concrete plant has an area to set up RCA plant, it will bring into great benefit. Indirect cost can be used together, investment cost is reduced, and transportation of RCA is shorter.

- The model in simulation assumed that the RCA plant has to buy at least 0 baht per ton for demolished concrete. However, the RCA plant should obtain the money for demolished concrete disposal. This will lead revenue of a RCA plant higher. Therefore, if the government announces the law and enforce, this can improve the performance of RCA plant.

\section{Acknowledgement}

This study was supported by Faculty of Engineering, Kasetsart University.

\section{References}

[1] S. Tate. (n.d). Recycled Concrete at the 2012 OLYMPICS. [Online]. Available: http://www.concretenetwork.com/concrete/decorative/recycled-olympics.html

[2] Zhengzhou Yifan Machinery, Co. Ltd. (2015, Dec.10). Recycled Construction Aggregate Macbine from Yifan. [Online]. Available: E-mail: sale17@yfmac.com; Message: Re:RE: Recycled construction aggregate machine from yifan

[3] A. Ussawarujikulchai, T. Leelawat, and U. Uyastian, "Study of the guideline for construction and demolition waste management in Thailand," Pollution Control Department, German Technical Cooperation (GTZ) and Mahidol University, Bangkok, 2005

[4] P. Toonkasikorn, V. Tungjirapat, and C. Jaturapitukkul, "Strength and chloride resistance of recycled aggregate concrete containing ground rice husk ash," Journal of Thailand Concrete Association, vol. 2, no. 1, 2014.

[5] M. R. Mumbua, "Feasibility of using recycled aggregate in new concrete," University of Nairobi, Kenya, 2014.

[6] K. Sakai, "Recycling concrete-The present state and future perspective," presented at TCG-JSCE Joint Seminar, Athens, Nov. 2009.

[7] U. T. Ganiron, Jr., "Recycling concrete debris from construction and demolition waste," International Journal of Advanced Science and Technology, vol. 77, pp. 7-24, 2015.

[8] X. Duran, H. Lenihan, and B. O'Regan, "A model for assessing the economic viability of construction and demolition waste recycling-The case of Ireland," Resources, Conservation and Recycling, vol. 46, pp. 302-320, 2006.

[9] W. Zhaoa, R. B. Leeftinkb, and V. S. Rotterc, "Evaluation of the economic feasibility for the recycling of construction and demolition waste in China-The case of Chongqing," Resources, Conservation and Recycling, vol. 54, pp. 377-389, 2010.

[10] D. R. Wilburn and G. T. Goonan, "Aggregates from natural and recycled sources; Economic assessments for construction applications; A materials flow study," U.S. Geological Survey Circular 1176, Central Region, Denver, Colorado, Jun. 1998.

[11] O. F. Hassanein and A. S. Ezeldin, "Concrete recycling in Egypt for construction applications: A technical and financial feasibility model," International Journal of Environmental, Chemical, Ecological, Geological and Geophysical Engineering, vol. 7, no. 12, pp. 902-907, 2013.

[12] R. Pongsre, "Business plan of Taweesin crushing plant", M.S. thesis, Bangkok University, Thailand, 2010.

[13] Ministry of Commerce Thailand, Bureau of Trade and Economic Indices. (2016). Consumer Price Index (CPI). [Online]. Available: http://www.price.moc.go.th/en/content1.aspx?cid=1

[14] S. Raktaengan, "A feasibility study on stone and sand separator machine for a company in Bangkok," Chaing Mai University, Thailand, 2014.

[15] Department of Business Development. (2016). Business Data. [Online]. Available: http://www.dbd.go.th/ 
[16] Thailand Yellow Page. (2016). Search Engine in July 17, 2016. [Online]. Available: http://www.yellowpages.co.th/

[17] Bank of Thailand. (2016). Statistic. [Online]. Available: https://www.bot.or.th/Thai/Statistics/Pages/default.aspx

[18] Statistics and Information Systems Department, Statistics Office, "Key Economic Indicator," Bank of Thailand, June 30, 2016.

[19] Henan Fote Heavy Industry. (2015, Nov. 3). Enquiry: Budgetary Process of RCA TypeL. [Online]. Available: Email: sales101@sinoftm.com; Message: RE: Enquiry : Budgetary process of RCA TypeL

[20] T. Wedlock Weir Minerals, (2015, Oct. 31). Enquiry: Budgetary Process of RCA Type L. [Online]. Available E-mail: Tom.Wedlock@weirminerals.com; Message: RE: Enquiry : Budgetary process of RCA Type L

[21] Department of Primary Industrials and Mines. (2015). Eservice. [Online]. Available: http://www.dpim.go.th/eservice-eservice/index

[22] The Treasury Department. (2015). Land Price Estimation. [Online]. Available: http://www.treasury.go.th/ewt_news.php?nid=173

[23] Bangchak Petroleum Public Company Limited. (2016). History Retail Oil Prices. [Online]. Available: http://www.bangchak.co.th/en/oil-price-history.aspx

[24] J.W. Wittwer. (n.d.). Monte Carlo Simulation Basics. [Online]. Available: http://web.ntpu.edu.tw/ yml/yml/download/risk2009s/handout(14-2).pdf

[25] ASBDC Illinois Small Business Development Center, "Understand where you stand," in A Simple Guide to Your Company's Financial Statements, The State of Illinois, W.O. 12-021 100 9/11 IOCI 12-261, n.d., pp. 1-11.

[26] R. Traynor and R. Glaser, "The state of statements: Balance sheets, income statements and statements of cash flow," Feedback, vol. 19, no. 3, pp. 7-10 and 26, 2008.

[27] W. Workman. (2016). Capital Budgeting Decisions: Net Present Value (NPV), Internal Rate of Return (IRR), and Payback Period. [Online]. Available: https://www.subjectmoney.com/articledisplay.php?title=Capital $\% 20$ Budgeting $\% 20$ Decisions: $\% 20 \mathrm{Ne}$ $\mathrm{t} \% 20$ Present $\% 20$ Value $\% 20$ (NPV), $\% 20$ Internal $\% 20$ Rate $\% 20$ of $\% 20$ Return $\% 20$ (IRR), $\% 20$ and $\% 20$ Pay back\%20Period\#sthash.lmFXptZP.dpuf 